\title{
Medieval and Modern Concepts of Race and Ethnicity
}

\author{
Robert Bartlett \\ University of St. Andrews \\ St. Andrews, Scotland
}

Historians working in the present day, just like their medieval and early modern predecessors, are confronted with difficult choices when they write of human population groups. ${ }^{1}$ When, if at all, is it reasonable to employ the word race, the word nation, the word tribe? What collective term best describes, say, the Goths, the English, the Jews? What meaning does the concept "ethnic identity" have? It is hard to do without some collective terms, but neither the medieval nor the modern terminology of race and ethnicity is simple or uncomplicated. Even the distinction between those two central terms, race and ethnicity, is drawn in different ways by different people. In the United States both popular and official usage tends to associate race with the troubled history of white and black, while the term ethnicity summons up Italians, Irish, or Greeks, for example. Hence the former term suggests a distinction based on an inherited biological feature, skin color, while the latter points to cultural differences between groups. Recent large-scale immigration into the United States from Asia and Latin America has complicated the issue by posing the question of whether the categories Oriental and Hispanic belong to the question of "race" or the question of "ethnicity." For the historian, such usage is to be regarded as an interesting fact about the intellectual and political history of our own times but cannot itself provide a tool of analysis. The expedients of the U.S. Census or Immigration administration are no starting point for scholarly inquiry.

Among social scientists of the present generation ethnicity has a different set of connotations. For them it serves as an acceptable alternative to race, a word that many consider permanently unusable because of its association with racism. In the discourse of the social sciences, the word ethnicity with this meaning is recent, the first occurrence recorded in the Oxford English Dictionary dating to 1953. (An earlier meaning was “paganism," but 
this is not relevant here, although it is impossible not to cite this stunning instance from 1782: "From the curling spume of the celebrated Egean waves, fabulous ethnicity feigned Venus their idolatress conceived.”)

The first United Kingdom census to ask questions about ethnicity was that of 1991, and much interesting empirical data was obtained as a result. An attempt was also made to address the theoretical or conceptual issues involved in using the term. In the report Ethnicity in the 1991 Census published by the Office of National Statistics, the question is asked, "Do we really 'know' what 'ethnic' actually means?" The scare quotes around "know" and "ethnic" warn that the author wishes simultaneously to assert something and to retract it, and such hesitancy characterizes the discussion in this report. The author outlines three possible approaches to ethnicity: it is primordial, it is a constantly changing sense of group identity, it is situational. In the last case, the author writes, "there may be no single, unambiguous 'true answer' to a question about one's ethnic identity." 2

It is hard to countenance the idea that there could be a "true answer" to a question about one's ethnic identity. Ethnic identity results from a process of labelling (identification). This may be self-labelling, but labelling by others is also involved, since ethnic identity may be contested. In the 1930 s many people who considered themselves Germans were told they were not; they were Jews instead. It made a good deal of difference which label stuck. This labelling and self-labelling is also strategic and situational. To identify oneself or others in this way is almost invariably to claim something or deny something. To call oneself, or be called, "black" or "British" or "Irish" or "Jewish" is not a neutral statement of the obvious but a political and historical assertion, with implications for one's rights and relationships. Different identities can be asserted in different situations. It is certainly not the case that a "true answer" could be found.

The author of the theoretical discussion in Ethnicity in the 1991 Census concludes:

Ethnicity . . . is clearly not amenable to static categorization ... but despite its complexity it could at least be argued that it represents one possible way of conceptualizing social divisions and cleavages. The ontological status of "race" is, however, much less secure. There is now almost universal agreement in the literature that the biological notion of race should be rejected in favour of a view which sees the term as essentially merely a social construct. ${ }^{3}$ 
The "literature" referred to here is that of the current social sciences, where race is viewed as the bad old word and ethnicity as the acceptable new one. What is astonishing in the passage is the idea that race is "merely a social construct," with the implication that ethnicity is not.

An apparent parallel to the race/ethnicity tangle can be brought in at this point in the attempt to clarify issues. This is the sex/gender distinction. Those who use the terms sex and gender carefully are seeking to distinguish a chromosomal, biological distinction between people, something they are born with, and the forms of sexual identity they are socialized into. Breasts are one thing, lipstick another. This cannot be the distinction between race and ethnicity. As opponents of racism have repeatedly pointed out, there are no pure races; there are no clear-cut ways of grouping human beings into discrete biological populations. Ethnicity does not stand in the same relation to race as gender does to sex. Put another way, both race and ethnicity can only be at the gender end of the polarity.

This is not to deny that there is genetic and biological variation between human groups. Much of this is invisible, but some is highly visible: color of skin, shape of eye, type of hair. These biological differences do not themselves constitute race or ethnicity but are part of the raw materials from which race or ethnicity can be constructed — along with language, religion, political allegiance, economic position, and so on. The significance attached to visible genetic markers varies from society to society - the difference between the meaning of skin color in Brazil and in the Old South being a locus classicus in discussion of such issues.

Our own usage should be based on the intellectual value of the distinctions our terms embody. Dictates of fashion are obviously strong. Just as some people use gender simply as the acceptable modern version of sex and talk of gender ratios in the human population, so others feel, perhaps from noble motives, that the word race should be banned from our discourse. Neither group has enriched the terms of analysis. Revising our vocabulary is not in itself meritorious. To distinguish sex and gender is to observe the world in a more nuanced way. To relabel sex as gender has the intellectual value of preferring pine furniture to mahogany.

As regards the terms race and ethnicity, it is better to be both more radical and more reactionary. It must be possible to reclaim the word race from the racists. It is a short, everyday word. As long as it is made clear that race is not a biological category, then it is stylistically preferable to speak and write of races rather than of ethnic entities. Ethnicity and race both refer to the identifications made by individuals about the groups they belong to. If 
one word has a use, then the other does. One is not the dark side of the force in a Manichean dualism. For the rest of this discussion racial and ethnic will be treated as synonyms.

Before turning to the usage of medieval authors, there is one other large conceptual issue that must be addressed. This is the problem of distinguishing groups and identities of an ethnic or racial kind from religious ones. Especially in a period like the Middle Ages, when religion meant membership of a community much more than adherence to a set of principles or beliefs, there was a sense in which one was born a Christian, a Muslim, or a Jew, just as one was born English or Persian. The shape of ethnic identity and ethnic strife and that of religious identity and religious strife are identical, as some modern conflicts, such as those in Northern Ireland or Bosnia, show. Indeed, in Bosnia, the tendency has been to see a threecornered fight between Croats, Serbs, and Muslims - two ethnic categories and one religious category. Noel Malcolm's superb Bosnia: A Short History refuses to be drawn by the idea that these ethnicities are primordial. Indeed, when talking of the period prior to the nineteenth century, he avoids the terms Croats and Serbs altogether, referring instead to Catholic Bosnians and Orthodox Bosnians, alongside the Muslim Bosnians. If anyone were to doubt that ethnicity were situational and strategic, his example of the twentieth-century Bosnian Muslim leader, who had two brothers, one classified as a Serb, the other as a Croat, might help to convince. ${ }^{4}$ We do not have a simple word to denote both ethnic and religious identities and groups, but it is hard to find good intellectual grounds for distinguishing them.

The medieval terminology of race and ethnicity was no more straightforward than our own. Some of the key terms of medieval Latin usage, such as gens and natio, imply, etymologically, a concept of races as descent groups. Others, such as populus, do not. The actual semantic field of such terms can only be mapped by detailed investigation of individual usage. As an example of one medieval writer's mental and verbal habits and also of the problem in rendering those medieval patterns accessible to modern readers of English, the following section looks at William of Malmesbury's Gesta regum Anglorum (Deeds of the Kings of the English) and its recent translation in the respected series Oxford Medieval Texts. ${ }^{5}$

William, who was a monk at the Benedictine abbey of Malmesbury in southern England, wrote his history, which is a source of primary importance for the Anglo-Saxon and Norman period, in the 1120s. The word gens and its grammatical variants occur about one hundred times in the Gesta 
regum. It is obviously a basic component of William of Malmesbury's view of the world. The range of the term can be suggested by looking at the various ways it has been translated in the modern edition and translation. Primary responsibility for the translation belongs to Sir Roger Mynors (19031989), whose work was done in the 1950s and subsequently lightly revised by scholars of a younger generation, so the preferences are those of a classically educated Oxford scholar whose own university education took place in the early 1920s. He was expressly committed to a method of translation that aimed at good literary English even at the cost of literalness.

The most neutral possible translation of gens is "people," and this occurs frequently in the English version. Perhaps more highly charged is "nation" and this too is a common choice. Thus William's gens Anglorum tends to appear as either "the English people" or "the English nation." Sometimes the yet more specific "nationality" is preferred, as when William the Conqueror decides to promote no Englishman to high office in the church. The chronicler's nullum eius gentis becomes "no one of English nationality" (3.254; 470-71).

"Race" is not an especially favored translation, but it does occur. The languages of the Franks and of the Anglo-Saxons are similar because "both races" (ambae gentes) originally came from Germany (1.68; 98-99). Sometimes the context exercises a semantic pull. When we read of the depredations and attacks barbarorum paganorumque gentium, it is easy to see how the rendition "of barbarous and pagan tribes" could slip from the pen of an Oxford classicist. What is barbarous and pagan is tribal (2.114; 172-73).

The association of the word gens with biological descent is visible in more than one English counterpart. A barbarian is described as gente et animo barbarus - "a barbarian in blood and behaviour"; a noble Normannicae gentis is "of Norman stock"; while Bohemond, the Norman leader in southern Italy, who is loco Apulus, gente Normannus, is "Norman by family," not, more mnemonically, "Apulian by place, Norman by race" $(2.134,145$, 4.349; 212-13, 232-33, 608-9). "Blood," "stock," and "family" thus stress the breeding and pedigree connotations of gens.

William of Malmesbury's usage sometimes suggests that there may be gentes of more than one kind, specifically that one gens may be a subdivision of a larger gens. He is willing to call the Northumbrians, Mercians, East Anglians, and men of Kent gentes, but also refers continually to the gens Anglorum. A member of the "Kentish nation" (gens Cantuariorum) was also presumably a member of the "English nation," hence having more than one 
ethnic identity simultaneously $(1.88 ; 128-29)$. Nor do gentes have to be immutable. After the Viking conquests in northern and eastern England, the Northumbrians and the Angles coalesced with the Danes into one gens (2.125; 196-97), an example of what early medieval historians studying the Germanic and other peoples have termed ethnogenesis.

This brief survey of the use of one racial or ethnic term by one medieval author and its translation by one translator cannot, of course, enlighten more than a corner of the topic, but it highlights a few of the issues and may serve as a kind of bridge between discussion of modern and medieval terminology. The translator is confronted with a foreign language that has to be rendered into another tongue. The fundamental question concerns the closeness of the fit between the two sets of terms, foreign and native. Some might argue that a foreign word, like gens, should be translated by the same English word on each occasion, others, like Mynors, that it either cannot or need not be. If we do wish for word-for-word translation, there is the tricky issue of which English word to chose. As we have seen, in the space of one work by one author gens can be rendered "race," "nation," "people," "tribe," "stock," or "family." Mynors himself recognized that translation is not only an "enjoyable art" but also a "perilous" one. ${ }^{6}$

Perhaps this issue has been labored. Yet we must consider that it is very unlikely that William of Malmesbury's Gesta regum will be translated into English in its entirety again within the next century and, as Latinity becomes more and more a minority attainment, that translations of Latin texts will be the gateways to the culture of the Middle Ages much more than the texts in the original. For many generations Mynors's choices of words will dictate the impression the reader gains of this text. It may well be that there is no misrepresentation in imagining William of Malmesbury writing of "the English nation" or "barbarous tribes," but for most readers there will be no way of checking. The complex and individual contours of William of Malmesbury's gens have been cloaked by the translator's choices of ethnic and racial terms from modern English.

To move away from the individual case to a wider consideration of ethnic and racial terms among medieval writers, one can clearly see how such words as gens and natio fit in well with what can be called the genealogical idiom of much medieval thinking. This was a world in which blood and descent were seen as fundamental. A noble was generosus or gentle or gentil — "well born.” A serf was a nativus — "born unfree." Kin solidarities were central in shaping patterns of property, power, and violence. To people who 
constantly saw the fate and fortunes of individuals determined by their birth and descent, it was natural to conceptualize humanity in similarly genealogical terms.

One frequently held theory proposed that the different gentes descended from the three sons of Noah, with Shem's descendants receiving Asia, Ham's Africa, and Japheth's Europe. A further theory postulated that there were a total of 72 races, paralleling the 72 apostles sent out by Jesus according to chapter 10 of the Gospel of Luke in the Vulgate version. Moreover, most races had etymological founders, like Scota, daughter of Pharoah, ancestress of the Scots, or Brutus the Trojan, who gave his name to Britain and from whom the Britons descend. These various strands - the three sons of Noah, the 72 races, and etymological ancestors - could be combined into a complete family tree of all humanity.

This immediately points to a latent idiosyncrasy in the medieval genealogical idiom. For while the starting point or premise of such genealogical-ethnic thinking was that each race was a group of human beings of common biological descent, the specific biblically inspired form it took also maintained the common biological descent of all human beings, from Adam and Eve and from Noah and his wife. In Augustine's words, "Whoever is anywhere born a man, that is, a rational mortal animal, no matter what unusual appearance he presents . . . no Christian can doubt that he springs from that one protoplast ... if they are human, they are descended from Adam."' Hence, although it may seem that medieval racial thinking was just as biological as modern pseudoscientific racism, it had as inbuilt components the common descent of all human beings with, as a necessary corollary, the implication that races had developed over the course of time.

In fact, while the language of race in the Middle Ages may often seem primarily concerned with descent groups, a closer look shows that this genetic component was often overshadowed by considerations of a different order. Two of the most significant are, at the level of learned theory, the importance of ideas of environmental influence and, more generally, the consistent emphasis on the cultural and social component of ethnic identity.

The learned theory of the Middle Ages drew on an ancient tradition of geographical determinism. As one of the founding texts, the Hippocratic Airs, Waters, and Places, put it, "In general you will find assimilated to the nature of the land both the physique and the characteristics of the inhabitants." ${ }^{8}$ This belief, that climate and geography shape the bodies and 
characters of the different peoples, is obviously not logically incompatible with the theory that races are descent groups, but it stresses quite different things and contradicts the idea of a constant national character.

Environmental thinking was rarely value-free. It usually turned out that the best environment, the one with the most desirable results, was the author's own. A classic instance is to be found in Aristotle's Politics:

Those who live in a cold climate and in Europe are full of spirit but wanting in intelligence and skill, and therefore they keep their freedom but have no political organization, and are incapable of ruling over others. Whereas the natives of Asia are intelligent and inventive, but they are wanting in spirit and therefore they are always in a state of subjection and slavery. But the Hellenic race [genos] which is situated between them, is likewise intermediate in character, being high-spirited and intelligent. ${ }^{?}$

The history of orientalism obviously begins here.

Medieval geographic determinism, drawing on classical roots, addressed itself to the influence of the physical environment on both physique and temperament. "Human beings vary in appearance and colour, in size of body and quality of mind, according to the skies above them," wrote Isidore of Seville, the great encyclopedist of the seventh century. ${ }^{10}$ In the twelfth century the ethnographic writer Gerald of Wales employed climatic and environmental theories in a variety of ways, reiterating the orientalist notion that the delicate air of the East produced people who were cunning but physically weak, more likely to conquer through underhanded use of poison than by force, and advancing the ingenious idea that the devil adapted his temptations to the particular physical dispositions of people: Arabs were hot, hence lustful, and ready to follow the lure of polygamous Islam, while in northwest Europe, with its cold, avaricious inhabitants, the Cathar heresy could gain ground by advocating nonpayment of tithes. ${ }^{11}$

Skin color was an aspect of human variability that lent itself naturally to environmental explanation - as it still does today. The thirteenthcentury encyclopedia of Bartolomaeus Anglicus reasoned that "cold is the mother of whiteness and of paleness, as heat is the mother of blackness and of redness. So in hot lands come forth black men and brown, as among the Moors, in cold lands white men, as among the Slavs." 12 The great Dominican scholar Albertus Magnus, whose treatise De natura locorum ("On the Nature of Places") is a systematic treatment of the influence of physical 
environment, advanced a similar opinion. "Everything generated in a place," argues Albertus, "derives its natural properties from that place." This "everything" includes the mental and physical properties of human beings. Heat and cold are especially formative: Indians are good at mathematics and magic, because a little heat leads to mental subtlety, but blacks are stupid because they are exposed to too much heat. Human blackness and whiteness are linked to the heat and cold of the environment. Crucially, over the course of generations, blacks in cold climates would become white. ${ }^{13}$ As the last point makes clear, environmental theory postulated the variability of races over time, with even such a manifest marker as skin color being liable to change. Medieval thinkers who took climatic and geographical determinism seriously would clearly find it hard to believe in timeless descent groups of fixed nature.

An even sharper contrast with a primordial biological view of race is found in the common emphasis that medieval authors placed on the cultural component of ethnic identity. For the majority of medieval writers, ethnicity was defined by and manifested in culture as much as, or more than, descent. The classic and much-quoted definition of Regino of Prüm (d. 915) asserts that "the various nations differ in descent, customs, language and law" [diversae nationes populorum inter se discrepant genere, moribus, lingua, legibus]. ${ }^{14}$ Of the four criteria listed here, only one is biological. Customs, language, and law are the outcome of socialization and hence are changeable. Such a cluster of terms as "customs, language and law" was an absolutely standard part of the thinking of medieval authors when it came to describing ethnic identity. In the twelfth century, when Bishop Bernard of St. Davids wrote to Innocent II arguing for a separate Welsh archdiocese, one of his grounds was that "the peoples of our province are distinct in nation, language, laws and customs, judgements and manners" [populos nostre provincie natione, lingua, legibus et moribus, iudiciis et consuetudinibus discrepare]. 15 The doublets "laws and customs" and "judgements and manners" are likely to be mere stylistic variation, referring in fact to laws/judgements as one category and customs/manners as another and thus leaving us with exactly the same four categories as Regino-descent, language, law, and customs.

Some of the intricacies of the medieval terminology of race and ethnicity are illustrated by the following long passage from the fourteenthcentury Scottish chronicler John of Fordun, describing the contrasts between the highlanders and the lowlanders (key words in the Latin are emphasized): 
The manners of the Scots vary according to their language, for they employ two languages, Scottish [Gaelic] and Teutonic [Scots/English]. The race of Teutonic language has the sea coasts and lowlands, that of Scottish language inhabits the mountainous areas and the outer isles. The race of the sea coasts is domesticated, civilized, faithful, patient, cultivated, decently dressed, refined and peaceable, devout in church worship, yet always ready to withstand any harm done by its enemies. The island or mountain race, however, is wild, untamed, primitive, intractable, inclined to plunder, leisure-loving, quick to learn, skilful, handsome in appearance but vilely dressed, and continually fiercely opposed to the English people and language, but also to their own nation, on account of the difference of language. Nevertheless they are loyal and obedient to the king and the kingdom, and also easily subdued to the laws, if they are ruled properly.

\section{[Mores autem Scotorum secundum diversitatem linguarum} variantur; duabus enim utuntur linguis, Scotica videlicet et Theutonica, cuius linguae gens maritimas possidet et planas regiones, Scoticae vero montanas inhabitat et insulas ulteriores. Maritima quoque domestica gens est et culta, fida, patiens et urbana, vestitu siquidem honesta, civilis atque pacifica, circa cultum divinum devota, sed et obviandis hostium iniuriis semper prona. Insulana vero sive montana, ferina gens est et indomita, rudis et immorigerata, raptu capax, otium diligens, ingenio docilis et callida, forma spectabilis, sed amictu deformis, populo quidem Anglorum et linguae, sed et propriae nationi, propter linguarum diversitatem, infesta iugiter et crudelis. Regi tamen et regno fidelis et obediens, necnon faciliter legibus subdita, si regatur.] ${ }^{16}$

The fact that he writes of the hostility of the highlanders "to their own nation" makes it clear that Fordun sees the Scots as a nation (natio) but a nation composed of two races (gentes). Each race is associated with a language (lingua) and the customs (mores) of the two races vary concomitantly with the languages. Here again, then, is the fundamental constitutive agency of language and customs - culture creates ethnicity.

The central place of language in defining ethnicity emerges strongly in Fordun's very grammar: cuius linguae gens, "the race of that language." A 
race can thus be specified by reference to its language. The intimate relationship between the two is reflected in the fact that in many medieval languages, including Latin, there were terms that could be translated either as "people" or as "language." For some medieval thinkers languages were indeed even more permanent parts of the human dispensation than races. In the early twelfth century, the chronicler Henry of Huntingdon, reflecting on the disappearance of the Picts, a people he had read about in the pages of Bede and elsewhere, made the telling observation:

The extinction of their kings and princes and the people itself and the passing away of the Pictish stock and language and even their mention, should inspire us to love heavenly and enduring things and shrink from earthly and transient things. And if nothing else is remarkable, what is truly astonishing is the disappearance of their language, that God created, among the rest, at the origin of languages. ${ }^{17}$

The disappearance of a people is less remarkable than the extinction of one of the languages that formed part of the divine plan.

When Fordun catalogues the "customs or manners of the Scots" (mores Scotorum), what he lists are all social or psychological features, such as refinement, wildness, or piety. This is certainly not the only possible meaning of "customs": such features as hair-style, methods of waging war, and types of music, for example, could be and often were analyzed as part of a people's culture by medieval observers. Fordun does mention dress but in a characteristically general and moralizing way. Most of what he says is either praise or blame. As C. S. Lewis pointed out, people like to express approval or disapproval of things much more than they like describing them. ${ }^{18}$ Hence we are constantly reading in the ethnographers of the Middle Ages such phrases as gens silvestris, gens spurcissima, gens crudelissima ("a savage race," "a foul race," "a most cruel race"). ${ }^{19}$ Hence, too, those lists of one-word, usually negative, characterizations of peoples that circulated in the period: "The envy of the Jews, the cunning of the Greeks, the pride of the Romans, the greed of the Franks, the commerce of the Gauls [men of the Low Countries?], the courage of the Saxons, the rage of the Bretons (or Britons), the boasting of the Picts, the lust of the Scots. . . ." It is often possible to guess from these characterizations the writer's own ethnic self-identification: "The knowledge of the French, the thirst of the English, the ignorance of the Bretons and the pride of the Normans grow with each year." 20 
The adjectives in Fordun's pen-portraits of lowlanders and highlanders provide a good menu of the terms used to describe civilization and barbarism in the medieval period. Culta, fida, patiens, urbana, vestitu honesta, civilis, pacifica constitute a full and powerful repertoire denoting the approved qualities of peace, predictability, and polish. The lowland race is, nevertheless, not a flock of supine Asiatics, but "always ready to withstand any harm done by its enemies." The highland people are, by contrast, ferina, indomita, rudis, immorigerata, raptu capax, otium diligens - a wild and primitive bunch of lazy, good-for-nothing cattle thieves. Yet Fordun does let slip a word of admiration for them. They are quick-witted and handsome, even if they spoil their good looks by foul clothing. John of Fordun took his name from Fordoun in eastern Scotland, a place situated only a few miles from "the Highland Line," the conventional division between lowlands and highlands, and would have had first-hand experience of both "races" that made up the Scottish "nation."

In this passage Fordun not only describes how "the Scots" are made up of two cultures or ethnicities, he also reflects upon the political consequences of such a situation. Although the highlanders are so fierce, and innately hostile both to the lowlanders and to the English, they are "loyal and obedient to the king and the kingdom, and also easily subdued to the laws, if they are ruled properly." The assumption here is that a kingdom need not be composed of merely one gens and that such multiethnic political units do not represent problems or anomalies. Furthermore, Fordun's language suggests that the concept of "nation" (natio), that apparent cornerstone of the genealogical idiom, can be adapted to describe a political entity made up of more than one race-for he explicitly states that the highland and lowland gentes are part of one natio.

Political units composed of more than one ethnic unit were familiar features of the medieval European world. When the Holy Roman Emperor, Charles IV, encouraged the Electors of the Empire to learn foreign languages, in the Golden Bull of 1356, his rationale was that the Empire oversaw the laws and government "of various nations, distinct in their customs, life and language." ${ }^{21}$ In a phrase from a medieval Hungarian tract, much cited by modern historians, we even encounter an explicit eulogy of the multiethnic state: "a kingdom of one race and custom is weak and fragile." 22 The Hungarian statement about the fragility of a "kingdom of one race and custom" implies that what matters in a polity is allegiance to a dynasty, not one's language or descent or even, within limits, one's religion. In this it parallels the modern concept of citizenship, where creed and color 
are meant to be irrelevant. Fordun's Scotland, with its two races and languages, but one nation and kingdom, was but one embodiment of this way of conceiving the relationship between ethnicity and political power.

However, it would be wrong to suggest that political claims based on common "ethnicity" were never raised in the Middle Ages. If ethnicity is situational and strategic, it is highly likely that it would be invoked when expedient; and it was. An example from the tenth century shows exactly the same kind of thinking about national territory that could be found amongst the delegates at Versailles after the First World War. Liudprand of Cremona, arguing in 968 against the Byzantine claim to southern Italy, asserted that "the race and language of the inhabitants [gens incola et lingua] makes it clear that that land is part of the kingdom of Italy." 23 The proper political allocation of the region, according to this view, should be dictated by the race and language of the inhabitants. It was very unlikely that Liudprand seriously believed that this was a principle of universal application - it would, amongst other things, have deprived his master, the emperor Otto I, of French-speaking Lotharingia — but it was a serviceable debating point to counter Byzantine claims.

At other times ethnic relationships were invoked in the attempt to create political alliances. Trying to rustle up support in 1278, the king of Bohemia addressed the Poles as "the nation of Poland, so similar to us [i.e., the Czechs]." He spoke of "the consonance of language," "contiguity of place," and "unity of blood and relationship" between Poles and Czechs, concluding by warning that, if the Poles did not help him, the "insatiable biting of the Germans” would go unchecked. ${ }^{24}$ Early in the following century the Bruce dynasty, fighting for Scottish independence under its own rule, appealed both to the Irish and to the Welsh as allies, invoking common ancestry and relationship and, in the case of the former, adducing also "common language." 25 In such cases as these, those making the appeals calculated that there was some strength and meaning in calling up common descent and language and that a feeling of ethnic and linguistic solidarity might shape and direct political action. In the case of the Bruce appeal, there was also a conscious tactic of silently ignoring what was by the fourteenth century the dominant component in the culture and identity of most inhabitants of Scotland, namely, the Scots-speaking lowlanders (Fordun's "race of Teutonic language"), in favor of its Gaelic side.

Modern nationalism at its crudest posits primordial and irreducible units called nations, each of which has the right to its own state. Medieval thinkers often drew political conclusions from race, but not usually this one. 
There was not a strong or predominant line of thought that a gens or a natio with its own law and language had to be a sovereign political entity. When, for example, the Welsh raised arguments for their autonomy during the final encounter of the house of Gwynedd with Edward I, they made the following case: Edward rules various countries (patriae) and tongues, with their own laws; let the laws of Wales have the same status as the laws of other peoples (nationes); the Welsh natio should have its own law and custom, just as the other nationes under the king, that is, the Gascons, Scots, Irish, and English, "have their own laws and customs according to their lingua" [suas leges et consuetudines secundum linguam suam habent]. ${ }^{26}$ Again we see the four cardinal points of difference-natio, lingua, leges, consuetudines. A nation with its own language should have its own laws and customs; it did not insist on political sovereignty. Edward I ruled a number of countries, with their own languages and customs, just like Charles IV's Holy Roman Empire. There was no requirement that political boundaries coincide with linguistic or legal ones, simply a recognition that each ethnic entity had the right to its own language and law.

Exactly the same principle was expressed by Duke Sobieslaw II of Bohemia when he defined the rights of the Germans resident in Prague around 1177. His charter based their distinctiveness on the fact that "just as the Germans are different from the Bohemians (Czechs) by nation, so they should be distinct from the Bohemians in their law and custom." 27 He was not abandoning political authority over them, but recognizing that the different "nations" under his rule should have their own distinct legal regimes. Charles IV, ruling in Prague two centuries later, would, as we have seen, have agreed.

There is a curious and significant parallel between one of the clauses of Sobieslaw's charter and another document from a quite different part of medieval Europe. Sobieslaw ruled that if a Czech brought a case against a German, he had to produce as witnesses two Germans and one Czech, while if a German brought a case against a Czech, he should produce two Czech witnesses and one German. In exactly the same spirit, the customs of the Catalan town of Tortosa ruled that a Christian must prove a case against a Muslim with at least two Muslim witnesses, and a Muslim must prove a case against a Christian with at least two Christian witnesses. ${ }^{28}$ The similarity between the two provisions illustrates the impossibility of distinguishing ethnic and religious difference in the medieval period. The situations are identical: distinct communities living in the same town and under the same ruler but with their own identities, constituted, in theory, by 
descent, language, laws, and customs. One of the "laws" that distinguished the Spanish Muslims and Christians was their religion, while this was not true of Germans and Czechs. Otherwise the social environments, problems, and solutions are exactly alike. Medieval rulers could expect to preside over different legal and linguistic communities, many also over different religious communities. It was only in very particular circumstances that it mattered which was which.

Of course, the degree of ethnic diversity varied in the different parts of medieval Europe. So did the degree of political centralization and unity. There was, however, no direct connection between ethnic and political homogeneity. The variety of situations is well exemplified in the British Isles, where three of the possible relationships occurred: in early medieval Ireland and Wales, a high degree of cultural unity coexisted with marked political fragmentation; in Scotland a unified kingdom emerged, formed of territories of great cultural and ethnic diversity; in England there was a relatively close match between the kingdom of England and the English people, producing what has been called a "regnal and ethnic solidarity." ${ }^{29}$ Each of these situations could generate nationalism, but they were nationalisms of different types. We have seen already some of the complexities of Scottish nationalism in the fourteenth century, with the passage from Fordun and the "pan-Celtic" propaganda of the Bruces presenting quite different Scotlands for their own purposes, both, however, clearly envisaging a political unit, the kingdom of Scots, as the proper, natural, and desirable vehicle of whatever national feeling they were invoking. England is a simpler case. A longish history of political unity under one dynasty, a common language, and the territorial integrity aided by an island location all created a "match between people and polity" that gave English nationalism an earlier, more continuous, and more apparently self-evident history than the nationalism of most other parts of Europe. 30

Medieval conceptions of race and nation are so tightly linked that it is virtually impossible to draw up a bibliography of medieval nationalism that is not also a bibliography of medieval ethnicity. On the other hand, perhaps, for the history of the nineteenth and twentieth centuries the two strands can be distinguished. The medieval situation was one where "race" almost always means the same thing as "ethnic group." Outside the slave markets of Genoa and such places, visible somatic features were relatively unimportant markers. Communities were differentiated by language and customs, the latter including law and religion. These groups claimed the right to distinctive treatment but rarely an inherent political sovereignty or a 
homeland. In many places there was an ethnic legal pluralism that fitted comprehensibly into a wider legal pluralism of noble, free, and unfree, of clerk and lay, of liberties and enclaves. The jural uniformity to which the modern state aspires was absent from the social landscape.

Just as actual biological descent was only one of the potential components from which a "race" or "ethnic group" could and can be constructed, so too these races or ethnic groups or nations were only one strand in the formation of political consciousness and the construction of political units. It may well be that by the year 1500 one could say that "English speaker," "subject of the king of England," and "Englishman (or woman)" were virtually synonyms, but that situation, of reinforcing rather than overlapping identities, was a rare case and one which was far from common in the medieval period. People label themselves, and are labelled, by many different things at different times for different purposes. It is not always necessary or desirable to have a group or identity of primary allegiance. Medieval terminology may have allowed a biological or genetic construal of race, but it also allowed a picture of races as changing cultural communities, often in competition, often forming and reforming, overflowing and cutting across political boundaries, providing identities and claims for their members. That seems to have been the "true answer" to the question about ethnic identity, in the Middle Ages as now.

3

\section{Notes}

1 Some of the issues discussed in this essay are addressed in Robert Bartlett, The Making of Europe: Conquest, Colonization, and Cultural Change, 950-1350

(Princeton: Princeton University Press, 1993), 197-242.

2 Ethnicity in the 1991 Census, 4 vols. (London: Office of National Statistics, 1996), $3: 2-3$.

3 Ibid., 3.

4 See Noel Malcolm, Bosnia: A Short History (New York: New York University Press, 1994), xi, 166.

5 William of Malmesbury, Gesta regum Anglorum, ed. and trans. R. A. B. Mynors, R. M. Thomson, and M. Winterbottom, vol. 1, Oxford Medieval Texts (Oxford: Clarendon Press, 1998). Book and section are given first, followed by page numbers.

6 Quoted in Michael Winterbottom's obituary of Mynors, Proceedings of the British Academy, "1991 Lectures and Memoirs," 80 (1991): 371-401, at 394.

7 Augustine, De civitate Dei 16.8; ed. B. Dombart and A. Kalb, Corpus Christianorum, 
Series Latina 47-48, 2 vols. (Turnhout: Brepols, 1950), 2:508-10. Translations here and following are my own unless otherwise noted.

8 Airs, Waters, Places, in Hippocrates, trans. W. H. S. Jones, Loeb Classical Library (London: Heinemann, 1923), 24.

9 Aristotle, Politics 7.7 (1327b 23); trans. B. Jowett (New York: Random House, 1941), 1286.

10 Isidore of Seville, Etymologiae 9.2.105; ed. W. M. Lindsay, 2 vols. (Oxford: Clarendon Press, 1911), n.p.

11 See Robert Bartlett, Gerald of Wales, 1146-1223 (Oxford: Clarendon Press, 1982), 201-5.

12 Bartolomaeus Anglicus, De proprietatibus rerum 4.2 (Frankfurt, 1601; repr. in facsimile, Frankfurt: Minerva, 1964).

13 Albertus Magnus, De natura locorum 2.2-4; ed. A. Borgnet, Opera omnia, 38 vols. (Paris, 1890-99), 9:560-65.

14 Regino of Prüm, Epistula ad Hathonem archiepiscopum missa, ed. Friedrich Kurze, Reginonis Abbatis Prumiensis Chronicon, Monumenta Germaniae historica, Scriptores rerum Germanicarum in usum scholarum separatim editi (Hanover, 1890), xix-xx.

15 Gerald of Wales (Giraldus Cambrensis), Invectiones 2.7; ed. W. S. Davies, $Y$ Cymmrodor 30 (1920): 142.

16 John of Fordun, Chronica gentis Scottorum 2.9; ed. W. F. Skene, 2 vols. (Edinburgh, 1871-72), 1:42. This is a much-discussed passage; see, for example, Alexander Grant, "Aspects of National Consciousness in Medieval Scotland," in Claus Bjørn et al., eds., Nations, Nationalism, and Patriotism in the European Past (Copenhagen: Academic Press, 1994), 68-95, at 76-77.

17 Henry of Huntingdon, Historia Anglorum 1.8; ed. Diana Greenway, Oxford Medieval Texts (Oxford: Oxford University Press, 1996), 24. See also Robert Bartlett, England under the Norman and Angevin Kings (Oxford: Clarendon Press, 2000), 662.

18 C. S. Lewis, Studies in Words, 2nd ed. (Cambridge: Cambridge University Press, $1967), 7$.

19 Gerald of Wales (Giraldus Cambrensis), Topographia hibernica 3.10, 19, 28; in his Opera, ed. J. S. Brewer, J. F. Dimock, and G. F. Warner, 8 vols., Rolls Series (London, 1861-91), 5:150, 164, 174.

20 Hans Walther, "Scherz und Ernst in der Völker- und Stämme-Charakteristik mittellateinischer Verse," Archiv für Kulturgeschichte 41 (1959): 263-301, at 277, 270.

21 Monumenta Germaniae historica, Constitutiones et acta publica imperatorum et regum 11, fasc. 7, ed. Wolfgang Fritz (Weimar: H. Böhlaus, 1988), Die Goldene Bulle, cap. 31, pp. 630-32.

22 Libellus de institutione morum, ed. J. Balogh, Scriptores rerum Hungaricarum 2 (Budapest: Academia litter. hungarica, 1938), 611-27, at 625.

23 Liudprand of Cremona, Legatio 7; ed. Albert Bauer and Reinhold Rau, Quellen zur Geschichte der sächsischen Kaiserzeit, Ausgewählte Quellen zur deutschen Geschichte des Mittelalters 8, rev. ed. (Darmstadt: Wissenschaftliche Buchgesellschaft, 1977), 530.

24 Regesta diplomatica nec non epistolaria Bohemiae et Moraviae, ed. K. J. Erben, et al., 7 vols. to date (Prague: Historicky ustav, Ceskoslovenská akademie ved., 1854-), vol. 2, no. 1106, pp. 466-68. 
25 The Acts of Robert I, King of Scots, 1306-1329, ed. Archibald Duncan, Regesta regum Scottorum, 1153-1424, vol. 5 (Edinburgh: Edinburgh University Press, 1988), no. 564, p. 695; J. B. Smith, "Gruffydd Llydd and the Celtic Alliance, 1315-18," Bulletin of the Board of Celtic Studies 26 (1974-76): 463-78, at 478.

26 Welsh Assize Roll, 1277-84, ed. James Conway Davies (Cardiff: University of Wales Press Board, 1940), 266.

27 Herbert Helbig and Lorenz Weinrich, eds., Urkunden und erzählende Quellen zur deutschen Ostsiedlung im Mittelalter, Ausgewählte Quellen zur deutschen Geschichte des Mittelalters 26, 2 vols. (Darmstadt: Wissenschaftliche Buchgesellschaft, 1968-70), vol. 2, no. 93, pp. 352-56.

28 John Boswell, The Royal Treasure: Muslim Communities under the Crown of Aragon in the Fourteenth Century (New Haven: Yale University Press, 1977), 123, citing the Costums of Tortosa IV. 11a. 29; ed. Ramón Foguet and José Foguet Marsal, Código de las costumbres escritas de Tortosa (Tortosa: Querol, 1912).

29 Rees Davies, "The Peoples of Britain and Ireland, 1100-1400, I: Identities," Transactions of the Royal Historical Society 6th ser., 4 (1994): 1-20, at 20. The whole sequence of papers, ibid. 5 (1995): 1-20; 6 (1996): 1-23; 7 (1997): 1-24, is of the highest value for discussions of ethnicity in the Middle Ages.

30 Davies, "Peoples of Britain," 19. 